\title{
HUBUNGAN ANTARA KONSENTRASI BELAJAR PESERTA DIDIK DENGAN KEAKTIFAN BELAJARNYA PADA \\ BIMBINGAN BELAJAR BAHASA INGGRIS HAPPY COURSE
}

Jurnal Pendidikan Luar Sekolah

http://kolokium.ppj.unp.ac.id/ Jurusan Pendidikan Luar Sekolah Fakultas Ilmu Pendidikan Universitas Negeri Padang Sumatera Barat, Indonesia

Volume 5, Nomor 2, Oktober 2017 DOI: 10.24036/kolokium-pls.v5i2.31

\author{
Yarissumi ${ }^{1,2}$ \\ 1Jurusan Pendidikan Luar Sekolah Fakultas Ilmu Pendidikan Universitas Negeri Padang \\ 2Email: yarisumy58@gmail.com
}

\begin{abstract}
ABSTRAK
Penelitian ini dilatarbelakangi oleh rendahnya keaktifan belajar peserta didik pada bimbingan belajar Bahasa Inggris Happy Course di Kabupaten Kerinci. Penelitian ini bertujuan untuk menemukan tingkat konsentrasi belajar peserta didik, keaktifan belajar peserta didik, dan hubungan antara konsentrasi belajar peserta didik dengan keaktifan belajarnya pada bimbingan belajar bahasa Inggris Happy Course di Kabupaten Kerinci. Jenis penelitian ini adalah kuantitatif korelasional. Populasi dalam penelitian ini berjumlah 64 orang. Adapun jumlah sampel dalam penelitian ini berjumlah 32 orang yang diambil 50\% dari populasi menggunakan teknik Cluster Random Sampling. Teknik pengumpulan data adalah angket, dan alat pengumpul data lembaran pernyataan. Teknik analisis data menggunakan rumus persentase dan Product Moment. Hasil penelitian menemukan bahwa konsentrasi belajar peserta didik dalam bimbingan belajar bahasa Inggris Happy Course berada pada kategori rendah, keaktifan belajar peserta didik berada pada kategori rendah, dan terdapat hubungan yang signifikan antara konsentrasi Belajar peserta didik dengan keaktifan belajarnya pada bimbingan belajar bahasa Inggris Happy Course di Kabupaten Kerinci.
\end{abstract}

Kata Kunci: Konsentrasi Belajar, Keaktifan Belajar

\section{PENDAHULUAN}

Lembaga bimbingan belajar memberikan kontribusi yang cukup besar terhadap pengembangan sumber daya manusia, peserta yang mengikuti bimbingan belajar ini biasanya para peserta didik yang mendapatkan kesulitan belajar terutama dalam memahami mata pelajaran tertentu, seperti peserta didik yang akan mengikuti ujian naik kelas, peserta didik yang akan mengikuti Ujian Nasional, dan peserta didik yang ingin mengikuti seleksi ujian untuk masuk Perguruan Tinggi Negeri.

Keaktifan belajar merupakan unsur dasar yang penting bagikeberhasilan proses pembelajaran. Menurut Dimyati \& Mudjiono (dalam Sagala, 2010), implikasi prinsip keaktifan bagi siswa lebih lanjut menuntut keterlibatan langsung siswa dalam proses pembelajaran. Keaktifan peserta didik, meliputi keaktifan untuk bertanya, mengemukakan pendapat, memperhatikan pada waktu pembelajaran. Lebih lanjut menurut Dimyati \& Mudjiono (dalam Sagala, 2010) pembelajaran adalah kegiatan guru secara terprogram dalam 
Hubungan antara Konsentrasi Belajar Peserta Didik dengan Keaktifan Belajarnya...

desain instruksional, untuk membuat siswa belajar secara aktif, yang menekankan pada penyediaan sumber belajar.

Ada beberapa faktor penyebab rendahnya keaktifan belajar peserta didik, seperti rendahnya minat peserta didik mengikuti bimbingan belajar bahasa Inggris, sulitnya memahami materi yang disampaikan instruktur, lingkungan di sekitar tempat pembelajaran tidak kondusif, sarana dan prasana kelas tidak lengkap, dan rendahnya konsentrasi peserta didik dalam memahami bahan pelajaran bahasa Inggris. Jika seorang peserta didik tidak dapat berkonsentrasi dalam belajar, bisa jadi ia tidak dapat menikmati proses belajar yang dilakukannya. Hal ini bisa saja dikarenakan mata pelajaran yang dipelajari dianggap sulit sehingga tidak dapat menyukai pelajaran tersebut, instruktur yang menyampaikan tidak disukai karena beberapa alasan, suasana dan tempat tidak menyenangkan, atau bahkan cara penyampaiannya membosankan. Gangguan konsentrasi pada saat belajar banyak dialami oleh peserta didik terutama dalam mempelajari mata pelajaran yang sulit untuk dipahami seperti mata pelajaran bahasa Inggris.

Peserta didik yang memiliki konsentrasi tinggi otomatis akan terlibat aktif dalam proses pembelajaran bahasa Inggris, sementara peserta didik yang kurang konsentrasi akan lambat mengerti dan menjadi pasif. Pada saat peserta didik pasif, peserta didik mengalami proses tanpa ada rasa ingin tahu, tanpa pertanyaan, dan tanpa ada daya tarik terhadap hasil belajar. Menurut Wibowo (2016), keaktifan belajar adalah suatu proses kegiatan belajar mengajar yang subjek didiknya terlibat secara intelektual dan emosional sehingga ia betulbetul berperan dan berpartisipasi aktif dalam melakukan kegiatan belajar.

Menurut Slameto (2010), konsentrasi adalah pemusatan pikiran terhadap suatu hal dengan menyampingkan semua hal lainnya yang tidak berhubungan. Dalam belajar konsentrasi berarti pemusatan pikiran terhadap suatu mata pelajaran dengan menyampingkan semua hal lainnya yang tidak berhubungan denngan pelajaran. Peserta didik yang berkonsentrasi belajar dapat diamati dari beberapa tingkah lakunya saat proses belajar mengajar berlangsung, seperti memperhatikan secara aktif setiap materi yang disampaikan instruktur, dapat merespon dan memahami setiap materi pelajaran yang diberikan, selalu bersikap aktif dengan bertanya dan memberikan argumentasi mengenai materi pelajaran yang disampaikan oleh instruktur, menjawab dengan baik dan benar setiap pertanyaan yang diberikan instruktur, dan tidak gaduh saat menerima materi pelajaran (Sunhaji, 2014).

Keaktifan belajar adalah suatu usaha dengan aktif dan giat warga belajar melakukan aktivitas-aktivitas dalam belajar. Keaktifan menurut Sriyono (1992), adalah bahwa pada waktu guru mengajar ia harus mengusahakan agar murid-muridnya aktif, jasmani maupun rohani. Keaktifan sendiri merupakan motor dalam kegiatan pembelajaran maupun kegiatan belajar, siswa dituntut untuk selalu aktif memproses dan mengolah hasil belajarnya. Untuk dapat memproses dan mengolah hasil belajarnya secara efektif, siswa dituntut untuk aktif secara fisik, intelektual, dan emosional.

Menurut Aini (2015), belajar adalah aktivitas manusia di mana semua potensi manusia dikerahkan. Kegiatan ini tidak terbatas pada kegiatan mental intelektual, tetapi juga melibatkan kemampuan-kemampuan yang bersifat emosional bahkan tidak jarang melibatkan kemampuan fisik. Rasa senang atau tidak senang, tertarik atau tidak tertarik, simpati atau antipati, adalah dimensi-dimensi emosional yang turut terlibat dalam proses belajar itu.

Tujuan penelitian ini adalah untuk melihat (1) gambaran konsentrasi belajar peserta didik pada bimbingan belajar Bahasa Inggris Happy Course, (2) gambaran keaktifan belajar 
peserta didik pada bimbingan belajar Bahasa Inggris Happy Course, (3) besarnya hubungan antara konsentrasi belajar peserta didik dengan keaktifan belajarnya pada bimbingan belajar Bahasa Inggris Happy Course.

\section{METODE}

Penelitian ini termasuk penelitian kuantitatif dengan jenis korelasional. Analisis korelasional merupakan kegiatan menganalisis data tentang hubungan atau ikatan antara variabel dalam suatu penelitian khususnya penelitian pendidikan dengan teknik-teknik statistik. Hal ini sejalan dengan pendapat Sugiyono (2014), menyatakan bahwa metode kuantitatif adalah data penelitian berupa angka-angka dan analisis menggunakan statistik.

Populasi merupakan keseluruhan objek penelitian sesuai dengan informasi yang diinginkan oleh si peneliti. Sesuai pendapat Sugiyono (2014), populasi adalah wilayah generalisasi yang terdiri atas objek/subjek yang mempunyai kualitas dan karakteristik tertentu yang ditetapkan oleh peneliti untuk dipelajari dan kemudian ditarik kesimpulan. Sesuai dengan tujuan yang penulis kemukakan, maka yang menjadi populasi dalam penelitian ini adalah semua peserta didik yang mengikuti bimbingan belajar bahasa Inggris Happy Course yang berjumlah 64 orang peserta didik.

Sampel merupakan bagian dari populasi yang terpilih dan mewakili populasi tersebut. Sesuai pendapat Sugiyono (2014), mengemukakan bahwa sampel adalah bagian dari jumlah dan karakteristik yang dimiliki oleh populasi tersebut. Teknik penarikan sampel yang digunakan dalam penelitian ini adalah Stratified Random Sampling, di mana populasi diambil berdasarkan tingkat pendidikan sebanyak 50\%. Adapun sampel dalam penelitian ini berjumlah 32 orang.

Menurut Arikunto (2013), sumber data adalah subjek dari mana data diperoleh. Sesuai dengan jenis data yang diambil dalam penelitian ini maka sumber data dalam penelitian ini adalah seluruh peserta didik yang mengikuti kegiatan bimbingan belajar bahasa Inggris Happy Course. Analisis data dalam penelitian ini adalah menggunakan rumus presentase.

$$
\mathrm{P}=\frac{f}{N} \times 100 \%
$$

Keterangan: $\mathrm{P}=$ Jumlah persentase

$f=$ Frekuensi jawaban

$N=$ Jumlah responden

Sementara untuk mengetahui hubungan antara variabel X (bebas) dengan variabel $\mathrm{Y}$ (terikat), digunakan rumus product moment, yaitu rumus yang dipergunakan rumus product moment yaitu sebagai berikut:

$$
r_{x y}=\frac{N \sum X Y-\left(\sum X\right)\left(\sum Y\right)}{\sqrt{\left.\left\{N \sum X^{2}-\left(\sum X\right)^{2}\right\} N \sum Y^{2}-\left(\sum Y\right)^{2}\right\}}}
$$


Hubungan antara Konsentrasi Belajar Peserta Didik dengan Keaktifan Belajarnya...

$\begin{array}{lll}\text { Keterangan: } & \mathrm{r}_{\mathrm{xy}} & =\text { Koefisien korelasi antara } \mathrm{x} \text { dan } \mathrm{y} \\ & \mathrm{XY} & =\text { Produk dari X dan } \mathrm{Y} \\ & \mathrm{X}^{2} & =\text { Jumlah } \mathrm{X} \text { pangkat } 2 \\ \mathrm{Y}^{2} & =\text { Jumlah } \mathrm{Y} \text { pangkat } 2 \\ \mathrm{~N} & =\text { Jumlah responden }\end{array}$

\section{HASIL PENELITIAN DAN PEMBAHASAN}

\section{Hasil Penelitian}

\section{Gambaran Konsentrasi Belajar Peserta Didik}

Data tentang konsentrasi belajar peserta didik pada bimbingan belajar bahasa Inggris Happy Course terdiri dari 3 (tiga) sub variabel, yakni: (1) fokus perhatian yang terdiri dari 8 (delapan) item, (2) mengikuti petunjuk instruktur yang terdiri dari 6 (enam) item, (3) tidak terusik oleh kegaduhan yang terdiri 4 (empat) item. Keseluruhan jumlah item adalah 18 (delapan belas) butir item.

Data konsentrasi belajar peserta didik dapat digambarkan dengan histogram berikut.

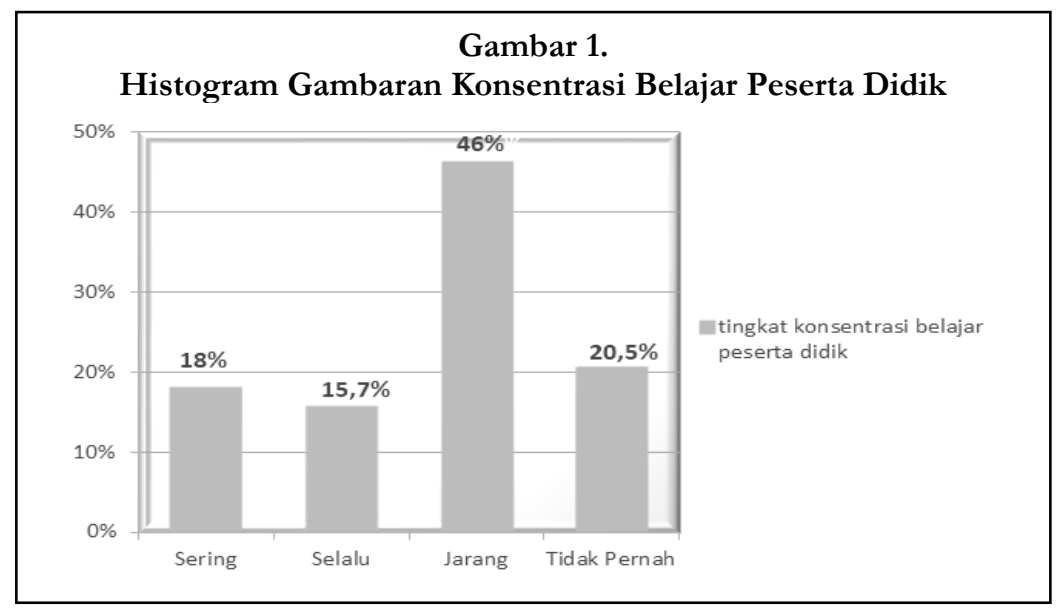

Gambar 1. menunjukkan bahwa sebagian besar peserta didik menjawab pada kategori jarang (JR). Hal ini berarti bahwa konsentrasi belajar peserta didik pada bimbingan belajar bahasa Inggris Happy Course rendah.

\section{Gambaran Keaktifan Belajar Peserta Didik}

Hasil penelitian dideskripsikan, dianalisis dan dilakukan pembahasan hasil pengolahan sesuai dengan tujuan penelitian yang telah dirumuskan yaitu untuk mengetahui gambaran keaktifan belajar peserta didik pada bimbingan belajar bahasa Inggris Happy Course di Kabupaten Kerinci. Data tentang tingkat keaktifan belajar peserta didik pada bimbingan belajar bahasa Inggris Happy Course di Kabupaten Kerinci terdiri dari 4 (empat) sub variabel yakni: (1) Keaktifan indera yang terdiri dari 6 (enam) item, (2) Keaktifan akal yang terdiri dari 6 (enam) item, (3) Keaktifan ingatan yang terdiri 5 (lima) item, (4) Keaktifan emosional yang terdiri dari 5 (lima) item. Keseluruhan jumlah item adalah 22 (dua puluh dua) butir item. 


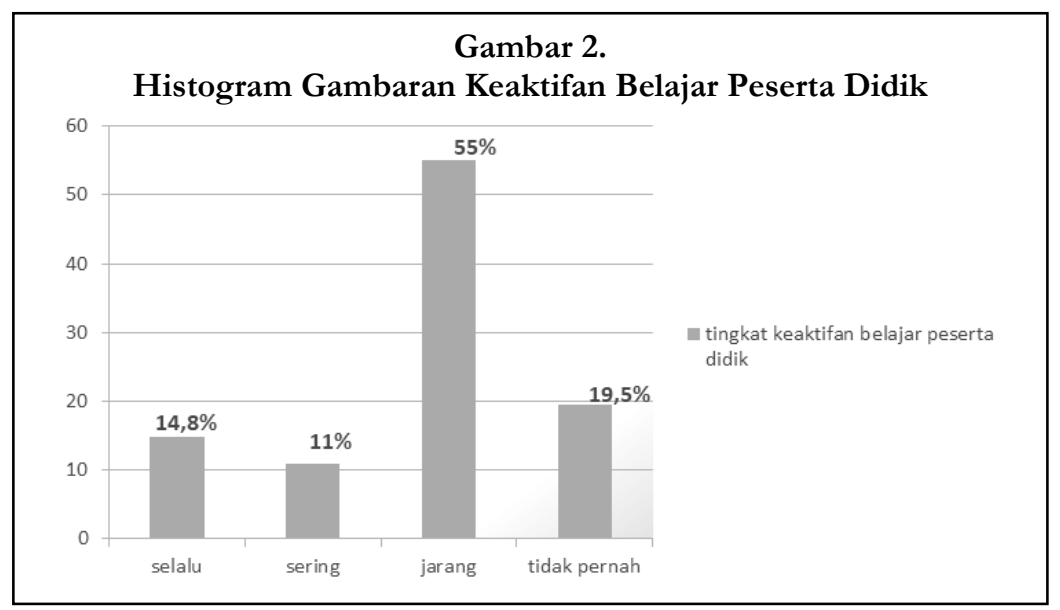

Gambar 2. menunjukkan bahwa keaktifan belajar peserta didik berada pada kriteria rendah. Hal ini berarti bahwa keaktifan belajar peserta didik pada bimbingan belajar Bahasa Inggris Happy Course tergolong rendah.

\section{Hubungan antara Konsentrasi Belajar Peserta Didik dengan Keaktifan Belajarnya}

Hipotesis yang diajukan dalam penenlitian ini adalah "terdapat hubungan yang signifikan antara konsentrasi belajar peserta didik dengan keaktifan belajarnya pada bimbingan belajar bahasa Inggris Happy Course di Kecamatan Keliling Danau Kabupaten Kerinci" yang dapat dilihat dari pengelolaan data berikut ini.

Tabel 1.

Koefisien Korelasi Hubungan antara Konsentrasi Belajar Peserta Didik (X) dengan Keaktifan Belajarnya (Y)

\begin{tabular}{cccccc}
\hline Responden & $\mathbf{X}$ & $\mathbf{Y}$ & $\mathbf{X Y}$ & $\mathbf{X}^{\mathbf{2}}$ & $\mathbf{Y}^{\mathbf{2}}$ \\
\hline 1 & 42 & 53 & 2226 & 1764 & 2809 \\
2 & 41 & 46 & 1886 & 1681 & 2116 \\
3 & 52 & 55 & 2860 & 2704 & 3025 \\
4 & 42 & 48 & 2016 & 1764 & 2304 \\
5 & 41 & 50 & 2050 & 1681 & 2500 \\
6 & 48 & 59 & 2832 & 2304 & 3481 \\
7 & 42 & 48 & 2016 & 1764 & 2304 \\
8 & 38 & 49 & 1862 & 1444 & 2401 \\
9 & 52 & 45 & 2340 & 2704 & 2025 \\
10 & 43 & 49 & 2107 & 1849 & 2401 \\
11 & 43 & 60 & 2580 & 1849 & 3600 \\
12 & 55 & 66 & 3630 & 3025 & 4356 \\
13 & 40 & 37 & 1480 & 1600 & 1369
\end{tabular}


Hubungan antara Konsentrasi Belajar Peserta Didik dengan Keaktifan Belajarnya...

\begin{tabular}{cccccc}
14 & 39 & 48 & 1872 & 1521 & 2304 \\
15 & 34 & 42 & 1428 & 1156 & 1764 \\
16 & 47 & 48 & 2256 & 2209 & 2304 \\
17 & 45 & 58 & 2610 & 2025 & 3364 \\
18 & 41 & 50 & 2050 & 1681 & 2500 \\
19 & 40 & 42 & 1680 & 1600 & 1764 \\
20 & 38 & 46 & 1748 & 1444 & 2116 \\
21 & 38 & 33 & 1254 & 1444 & 1089 \\
22 & 42 & 47 & 1974 & 1764 & 2209 \\
23 & 40 & 45 & 1800 & 1600 & 2025 \\
24 & 36 & 45 & 1620 & 1296 & 2025 \\
25 & 41 & 61 & 2501 & 1681 & 3721 \\
26 & 40 & 47 & 1880 & 1600 & 2209 \\
27 & 35 & 42 & 1470 & 1225 & 1764 \\
28 & 40 & 66 & 2640 & 1600 & 4356 \\
29 & 41 & 43 & 1763 & 1681 & 1849 \\
30 & 42 & 50 & 2100 & 1764 & 2500 \\
31 & 36 & 43 & 1548 & 1296 & 1849 \\
32 & 38 & 37 & 1406 & 1444 & 1369 \\
\hline Jumlah & $\mathbf{1 3 3 2}$ & $\mathbf{1 5 5 8}$ & $\mathbf{6 5 4 8 5}$ & $\mathbf{5 6 1 6 4}$ & $\mathbf{7 7 7 7 2}$ \\
\hline & & & & &
\end{tabular}

Mengacu pada Tabel 1. maka dapat diolah data melalui rumus product moment sebagai berikut:

$$
\begin{aligned}
& \mathrm{N}=32 \\
& \sum \mathrm{X}=1332 \\
& \sum \mathrm{Y}=1558 \\
& \sum \mathrm{XY}=65485 \\
& \sum \mathrm{X}^{2}=56164 \\
& \sum \mathrm{Y}^{2}=77772 \\
& r_{x y}=\frac{N \sum X Y-\left(\sum X\right)\left(\sum Y\right)}{\sqrt{\left\{N\left(\sum X^{2}\right)-\left(\sum X\right)^{2}\right\}\left\{N\left(\sum Y^{2}\right)-\left(\sum Y\right)^{2}\right\}}} \\
& r_{x y}=\frac{32(65485)-(1332)(1558)}{\sqrt{\left\{32(56164)-(1332)^{2}\right\}\left\{32(77772)-(1558)^{2}\right\}}} \\
& r_{x y}=\frac{2095520-2075256}{\sqrt{\{1797248-1774224\}\{2488704-2427364}} \\
& r_{x y}=\frac{20264}{\sqrt{\{23024\}\{61340\}}}
\end{aligned}
$$




$$
\begin{aligned}
r_{x y} & =\frac{20264}{\sqrt{1412292160}} \\
r_{x y} & =\frac{20264}{37580,47} \\
r_{x y} & =0,5392162 \\
r_{x y} & =0,540
\end{aligned}
$$

Analisis data di atas didapatkan rhitung $=0,540$ dengan menggunakan rumus product moment sedangkan rtabel pada taraf signifikan $95 \%=0,349$ dan rtabel pada taraf signifikan $99 \%=0,449$ dengan $\mathrm{n}=32$. Dengan demikian dapat dilihat bahwa rhitung $>$ rtabel. Berdasarkan hasil tersebut, maka dapat disimpulkan bahwa terdapat hubungan yang signifikan anatara konsentrasi belajar peserta didik dengan keaktifan belajarnya pada bimbingan belajar bahasa Inggris Happy Course di Kabupaten Kerinci.

\section{Pembahasan}

\section{Konsentrasi Belajar Peserta Didik}

Hasil penelitian yang didapatkan menunjukkan bahwa tingkat konsentrasi belajar peserta didik berada pada kategori rendah dan sangat rendah. Dapat disimpulkan bahwa konsentrasi belajar peserta didik pada bimbingan belajar bahasa Inggris Happy Course di Kabupaten Kerincirendah.

Konsentrasi belajar merupakan suatu hal yang sering terlibat di setiap aspek kehidupan seseorang sehari-hari, terutama seperti fungsi kognitif dan suatu relasi sosial. Berada dalam suatu pelajaran informal, duduk di dalam ruang kelas merupakan hal yang membutuhkan perhatian dalam waktu cukup lama dan dapat menjadi hal yang sulit dilakukan bagi beberapa orang. Kemampuan seorang pelajar dalam berkonsentrasi atau fokus secara efektif dapat memengaruhi keaktifannya dalam memperhatikan pelajaran dan mengerjakan tugas.

Menurut Surya (2009), konsentrasi adalah pemusatan daya pikiran dan perbuatan pada suatu objek yang dipelajari dengan mengahalau atau menyisihkan segala hal yang tidak ada hubungannya dengan objek yang dipelajari.Peserta didik yang mampu berkonsentrasi saat proses belajar mengajar berlangsung ialah peserta didik yang berada dalam keadaan sedang memperhatikan. sebagaimana pendapat Syardiansah (2016), konsentrasi dimaksudkan memusatkan segenap kekuatan perhatian pada suatu situasi belajar. Unsur motivasi dalam hal ini sangat membantu tumbuhnya proses pemusatan perhatian. Di dalam konsentrasi ini keterlibatan mental secara detail sangat diperlukan, sehingga tidak "perhatian" sekedarnya."

Setiap peserta didik mempunyai keterampilan yang berbeda-beda dalam hal belajar, seperti keterampilan membaca, mendengar, dan menulis yang mereka peroleh dari pengalaman belajarnya yang sudah pasti akan berpengaruh dengan prestasi belajar. Dengan prestasi belajar yang tinggi berarti suatu tujuan dari kegiatan belajar mengajar tercapai dengan baik. Setiap pendidik tentunya akan berusaha semaksimal mungkin memberikan materi belajar sesuai kebutuhan peserta didiknya agar mereka dapat berpartisipasi aktif dalam kegiatan pembelajaran dan dapat mencapai prestasi secara optimal. Untuk mencapai prestasi yang optimal, dibutuhkan suatu konsentrasi dari peserta didik agar proses belajar mengajar sesuai dengan tujuannya. 
Hubungan antara Konsentrasi Belajar Peserta Didik dengan Keaktifan Belajarnya...

Peserta didik yang mampu berkonsentrasi saat proses belajar mengajar berlangsung ialah peserta didik yang berada dalam keadaan sedang memperhatikan. sesuai pendapat Slameto (2010), konsentrasi adalah pemusatan pikiran terhadap suatu hal dengan menyampingkan semua hal lainnya yang tidak berhubungan. Artinya peserta didik tesebut dapat mengarahkan indera atau sistem persepsinya untuk menerima informasi tentang sesuatu yang sedang diterimanya. Namun, tidak semua peserta didik melakukan hal itu dengan baik. Sering munculnya off task behavior di dalam kelas sangat menghambat kegiatan belajar peserta didik, yaitu perilaku yang muncul selama mengikuti proses pembelajaran tetapi tidak mendukung kegiatan belajar. Seperti tidak semangat mengerjakan tugas, bicara sendiri selama mengikuti pelajaran, menulis atau menggambar yang tidak relevan dengan kajian bidang studi yang sedang diikuti, menyontek, melamun ketika mengikuti pembelajaran, dan lain-lain.

\section{Tingkat Keaktifan Belajar Peserta Didik}

Temuan penelitian dan hasil pengolahan data yang peneliti dapatkan dilapangan menunjukan bahwa keaktifan belajar peserta didik pada bimbingan belajar bahasa Inggris Happy Course di Kabupaten Kerinci sejumlah 66\% responden berada pada kategori rendah dan $9 \%$ pada kategori sangat rendah. Adapun responden yang berada pada kategori tinggi dan sangat tinggi yaitu 12,5\% dan 12,5\%. Dengan demikian, dapat disimpulkan bahwa keaktifan belajar peserta didik pada bimbingan belajar bahasa Inggris Happy Course di Kabupaten Kerinci tergolong rendah.

Belajar merupakan suatu kegiatan yang tidak terpisahkan dari kehidupan manusia. Belajar membuat manusia dapat mengembangkan potensi-potensi yang dibawanya sejak lahir. Menurut Syardiansah (2016), belajar itu senantiasa merupakan perubahan tingkah laku atau penampilan, dengan serangkaian kegiatan misalnya dengan membaca, mengamati, mendengarkan, meniru dan lain sebagainya. Berdasarkan beberapa pengertian tentang belajar di atas, dapat disimpulkan bahwa belajar merupakan suatu proses usaha yang dilakukan individu untuk mengadakan perubahan dalam dirinya secara keseluruhan baik berupa pengalaman, keterampilan, sikap dan tingkah laku sebagai akibat dari latihan serta interaksi dengan lingkungannya.

Dalam setiap proses belajar peserta didik harus selalu menampakkan keaktifan, baik dari kegiatan fisik maupun kegiatan psikis. Menurut Dimyati \& Mudjiono (dalam Sagala, 2010), keaktifan dalam bentuk kegiatan fisik bisa berupa membaca, mendengar, menulis, berlatih keterampilan-keterampilan, dan sebagainya. Contoh kegiatan psikis misalnya menggunakan khasanah pengetahuan yang dimiliki dalam memecahkan masalah yang dihadapi, membandingkan satu konsep dengan yang lain, menyimpulkan hasil percobaan, dan kegiatan psikis yang lain.

Keaktifan peserta didik dalam kegiatan belajar tidak lain adalah untuk mengkonstruksi pengetahuan mereka sendiri. Mereka aktif membangun pemahaman atas persoalan atau segala sesuatu yang mereka hadapi dalam proses pembelajaran. Dalam Kamus Besar Bahasa Indonesia aktif berarti giat (bekerja, berusaha). Keaktifan diartikan sebagai hal atau keadaan di mana peserta didik dapat belajar secara aktif.

Menurut Sriyono (1992), menyatakan keaktifan anak dalam mencoba atau mengerjakan sesuatu amat besar artinya dalam pendidikan dan pengajaran. Percobaanpercobaan yang ia lakukan akan memantapkan hasil studinya. Lebih dari itu akan 
menjadikannya rajin, tekun, tahan uji dan percaya pada diri sendiri. ia mempunyai rasa optimis dalam menghadapi hidup.

Uraian di atas dapat disimpulkan bahwa keaktifan peserta didik dalam belajar merupakan segala kegiatan yang bersifat fisik maupun nonfisik peserta didik dalam proses kegiatan belajar mengajar. Yang bertujuan untuk menciptakan suasana kelas menjadi kondusif. sehingga dapat membawa peserta didik pada hasil belajar yang optimal.

\section{Hubungan antara Konsentrasi Belajar peserta didik dengan Keaktifan Belajarnya}

Hasil analisis data yang diperoleh terdapat hubungan yang signifikan antara konsentrasi belajar peserta didik dengan keaktifan belajarnya pada bimbingan belajar bahasa Inggris Happy Course di Kabupaten Kerinci. Dengan demikian diterima kebenarannya karena rhitung $>$ rtabel. Hasil pengujian hipotesis antara konsentrasi belajar peserta didik (x) dengan keaktifan belajarnya (y) terdapat hubungan $r_{x y}=0,540$. Dengan demikian apabila konsentrasi belajar peserta didik rendah maka keaktifan belajarnya kurang aktif pula.

Belajar adalah suatu perubahan di dalam kepribadian yang menyatakan diri sebagai suatu pola baru dari reaksi yang berupa kecakapan, sikap, kebiasaan kepribadian atau suatu pengertian. Hanafy (2014), menyatakan bahwa belajar ialah suatu proses usaha yang dilakukan seseorang untuk memperoleh suatu perubahan tingkah laku yang baru secara keseluruhan, sebagai hasil pengalamannya sendiri dalam interaksi dengan lingkungannya. Dari pengertian di atas dapat diketahui bahwa belajar mengacu pada perubahan perilaku yang terjadi sebagai akibat dari interaksi antara individu dengan lingkungannya.

Dalam arti luas belajar diartikan sebagai perubahan tingkah laku yang dinyatakan dalam bentuk penguasaan, penggunaan, dan penilaian terhadap atau mengenai sikap dan nilai-nilai, pengetahuan dan kecakapan dasar yang terdapat dalam berbagai bidang studi. Setiap peserta didik mempunyai karakter yang berbeda-beda ketika mereka harus mengikuti proses belajar di kelas. Peserta didik yang cenderung asik dengan dunianya sendiri, mereka lebih suka mengobrol dengan teman duduknya daripada harus mendengarkan materi yang diberikan oleh instruktur, ada peserta didik yang hanya bisa fokus terhadap pelajaran jika suasana tenang, dan sejenisnya. peserta didik yang tidak dapat berkonsentrasi dalam belajar berarti tidak dapat memusatkan pikirannya terhadap bahan pelajaran yang dipelajarinya. Konsentrasi dalam belajar akan menentukan keberhasilan belajar, oleh karena itu maka setiap peserta didik perlu melatih konsentrasi dalam kegiatan sehari-hari.

Menurut Surya (2009), penyebab-penyebab timbulnya kesulitan konsentrasi belajar antara lain: (1) Lemahnya minat dan motivasi pada pelajaran; (1) Timbulnya perasaan negatif, seperti, gelisah, tertekan, marah, khawatir, takut, benci, dan dendam; (3) Suasana lingkungan belajar yang berisik dan berantakan; (4) Gangguan kesehatan jasmani; (5) Bersifat pasif dalam belajar; (6) Tidak memiliki kecakapan dalam cara-cara belajar yang baik.

Pentingnya konsentrasi belajar pada peserta didik sangat menentukan prestasi belajarnya, konsentrasi belajarnya tersebut dapat dilihat dari fokusnya peserta didik ketika belajar. Agar dapat berkonsentrasi dengan baik perlulah diusahakan beberapa hal misalnya, pelajar hendaknya berminat atau punya motivasi yang tinggi, ada tempat belajar tertentu dengan meja belajar yang bersih dan rapi, mencegah timbulnya kebosanan, menjaga kesehatan dan memperhatikan kelelahan, menyelesaikan masalah-masalah yang mengganggu dan bertekad untuk mencapai tujuan terbaik setiap kali belajar. 
Hubungan antara Konsentrasi Belajar Peserta Didik dengan Keaktifan Belajarnya...

Cara meningkatkan keterlibatan atau keaktifan peserta didik dalam belajar adalah mengenali dan membantu anak-anak yang kurang terlibat dan menyelidiki penyebabnya. Usaha apa yang bisa dilakukan untuk meningkatkan keaktifan peserta didik, sesuaikan pengajaran dengan kebutuhan-kebutuhan individual peserta didik. Hal ini sangat penting untuk meningkatkan usaha dan keinginan peserta didik untuk berpikir secara aktif dalam kegiatan belajar.

Keaktifan sendiri merupakan motor dalam kegiatan pembelajaran maupun kegiatan belajar. Peserta didik dituntut untuk selalu aktif memproses dan mengolah hasil belajarnya. Untuk dapat memproses dan mengolah hasil belajarnya secara efektif, peserta didik dituntut untuk aktif secara fisik, intelektual, dan emosional.

Agar terilbat aktif dalam pembelajaran bahasa Inggris peserta didik diharuskan dapat memiliki konsentrasi yang tinggi terhadap bahan pelajaran. Sesuai pendapat Mulyana, Izzati, \& Rahmasari (2013), seseorang yang dapat belajar dengan baik adalah orang yang berkonsentrasi dengan baik, dengan kata lain, ia harus memiliki kebiasaan untuk memusatkan perhatian. Jadi untuk terlibat aktif dalam pembelajaran bahasa inggris peserta didik dituntut agar dapat memusatkan perhatiannya secara penuh kepada bahan pelajaran.

Kurangnya konsentrasi peserta didik dalam belajar akan memengaruhi peserta didik dalam menerima bahan pelajaran yang disampaikan instruktur sehingga mengakibatkan rendahnya keaktifan peserta didik dalam belajar. Azizah (2015), menjelaskan konsentrasi besar pengaruhnya terhadap aktivitas belajar. Jika seeorang mengalami kesulitan berkonsentrasi, jelas belajarnya akan menjadi sia-sia, karena hanya membuang tenaga, waktu, dan biaya saja. Seseorang yang aktif dalam belajar adalah orang yang dapat berkonsentrasi dengan baik.

Menurut Setiani, Setyowani, \& Kurniawan (2014), jika peserta didik dapat memberikan perhatian secara intensif pada bahan pelajaran yang diberikan instruktur, maka peserta didik akan memperoleh pemahaman dan pengertian dengan baik. Demikian juga kemampuan peserta didik untuk konsentrasi belajar akan membuka simpul-simpul hasrat ingin tahu peserta didik tentang materi pelajaran secara terarah melalui paparan instruktur. Dengan adanya konsentrasi belajar memungkinkan peserta didik untuk lebih berpartisipasi aktif dalam mengikuti pembelajaran.

Peserta didik yang sudah bisa berkonsentrasi akan dapat belajar sebaik-baiknya kapan dan di mana pun juga. Bagi yang belum perlulah mengadakan latihan-latihan, karena kemampuan berkonsentrasi adalah kunci untuk berhasil dalam belajar. Dengan demikian dapat disimpulkan bahwa konsentrasi belajar merupakan salah satu kesulitan belajar peserta didik yang dikarenakan tidak fokusnya peserta didik terhadap materi yang ia terima karena faktor-faktor yang memengaruhinya. Konsentrasi belajar juga dipengaruhi oleh lingkungan sekitar di mana peserta didik itu belajar.

Uraian di atas dapat disimpulkan bahwa konsentrasi akan membantu peserta didik lebih memusatkan perhatiannya kepada bahan pelajaran sehingga akan membuat peserta didik lebih aktif belajar. Hal tersebut menjelaskan bawa semakin tinggi konsentrasi peserta didik dalam belajar bahasa Inggris maka semakin aktif peserta didik dalam proses pembelajaran. Sebaliknya, semakin rendah konsentrasi peserta didik dalam belajar bahasa Inggris, maka semakin tidak aktif peserta didik dalam proses pembelajaran. 


\section{KESIMPULAN}

Kesimpulan yang dapat diambil berdasarkan hasil penelitian dan pengolahan data tentang hubungan antara konsentrasi belajar peserta didik dengan keaktifan belajarnya pada bimbingan belajar bahasa Inggris Happy Course di Kabupaten Kerinci adalah sebagai berikut: Gambaran konsentrasi belajar peserta didik pada bimbingan belajar bahasa Inggris Happy Course rendah, gambaran keaktifan belajar peserta didik pada bimbingan belajar bahasa Inggris Happy Course terletak pada kategori rendah, terdapatnya hubungan konsentrasi belajar peserta didik dengan keaktifan belajarnya pada bimbingan belajar bahasa Inggris Happy Course di Kabupaten Kerinci.

\section{DAFTAR RUJUKAN}

Aini, S. N. (2015). Pengaruh Strategi Pembelajaran, Gaya Belajar, Sarana Paraktik, dan Media terhadap Hasil Belajar Patiseri SMK Se-Gerbangkertasusila. Jurnal Pendidikan Vokasi, 5(1), 88-102.

Arikunto, S. (2013). Prosedur Penelitian Suatu Pendekatan Praktik. Jakarta: Rineka Cipta.

Azizah, S. N. (2015). Peningkatan Konsentrasi dan Hasil Belajar IPA Melalui Mind Mapping Siswa Kelas V SDN Jomblangan. Jurnal Pendidikan Guru Sekolah Dasar, 5(4).

Hanafy, M. S. (2014). Konsep Belajar dan Pembelajaran. Lentera Pendidikan, 17(1), 66-79.

Mulyana, O. P., Izzati, U. A., \& Rahmasari, D. (2013). Penerapan Relaksasi Atensi untuk Meningkatkan Konsentrasi Belajar pada Siswa SMK. Jurnal Psikologi: Teori \& Terapan, 3(2), 103-112.

Sagala, S. (2010). Konsep dan Makna Pembelajaran. Bandung: Alfabeta.

Setiani, A. C., Setyowani, N., \& Kurniawan, K. (2014). Meningkatkan Konsentrasi Belajar Melalui Layanan Bimbingan Kelompok. Indonesian Journal of Guidance and Counseling, 3(1), 37-42.

Slameto. (2010). Belajar dan Faktor-factor yang Memengarubinya. jakarta: Rineka Cipta.

Sriyono, D. (1992). Belajar Mengajar dalam CBSA. Jakarta: Rineka Cipta.

Sugiyono, P. (2014). Metode Penelitian Pendidikan. Bandung: Alfabeta.

Sunhaji. (2014). Konsep Manajemen Kelas dan Implikasinya dalam Pembelajaran. Jurnal Kependidikan, 2(2), 30-46.

Surya, H. (2009). Menjadi Manusia Pembelajar. Jakarta: Elex Media Komputindo.

Syardiansah. (2016). Hubungan Motivasi Belajar dan Minat Belajar terhadap Prestasi Belajar Mahasiswa Mata Kuliah Pengantar Manajemen (Studi kasus Mahasiswa Tingkat I EKM A Semester II ). Jurnal Manajemen Dan Keuangan, 5(1), 439-448.

Wibowo, N. (2016). Upaya Peningkatan Keaktifan Siswa Melalui Pembelajaran Berdasarkan Gaya Belajar di SMK Negeri 1 Saptosari. Jurnal Electronics, Informatics, and Vocational Education (ELINVO), 1(2), 128-139. 